\title{
Economic Impact of Neem Coated Urea on Indian Agriculture: Evidence from a Benchmark Study
}

Ramappa Kumsher Basavarajappa ( $\square$ ramappa@rpcau.ac.in )

Central Agricultural University https://orcid.org/0000-0001-6407-5026

Vilas Jadhav

Agricultural Development and Rural Transformation Centre [ADRTC]

A.V Manjunatha

Agricultural Development and Rural Transformation Centre [ADRTC]

\section{Research Article}

Keywords: Partial budgeting Technique, Impact of NCU on crop yield and income, Sustainable Agriculture.

Posted Date: June 11th, 2021

DOl: https://doi.org/10.21203/rs.3.rs-575502/v1

License: @ (i) This work is licensed under a Creative Commons Attribution 4.0 International License. Read Full License 


\section{Abstract}

The policy of mandatory production and distribution of Neem Coated Urea (NCU) from May 2015, with a focussed attention on improving the soil quality through a judicious use of fertilizers seems to be in the right direction, considering the benefits realized so far by the Indian farming community. In this article, authors have made an attempt to explore the benefits recognized by the producers of six major crops such as paddy, maize, sugarcane, tur, jute and soybean across the six major states viz., Karnataka, Maharashtra, Madhya Pradesh, Bihar, Punjab and Assam with 2200 sample households. The reference period of the study was the immediate season (Kharif 2015) post the NCU production. The results reveal that NCU use has contributed positively in terms of increasing the yield levels of both main product and by-products with regard to almost all the reference crops under study. However, the extent varies from crop to crop, highest being in the case of soybean, followed by tur, maize, sugarcane, paddy and jute. While the net returns are highest in respect of tur, followed by paddy. As regards B:C ratio, tur tops the list subsequent to sugarcane, paddy, soybean, maize and jute. Moreover, NCU has helped reduce the cost of production by minimizing the cost of urea as well as of other fertilizers and pesticides usage. Interestingly, the diversion of urea has stopped completely, post the production and distribution of NCU. Hence, it is concluded that the application of NCU has a positive impact on Indian agriculture, by way of increasing yield levels \& returns for the farming community. These results are in line with the PM's vision of doubling farmers' income by 2022 and Sustainable Development Goals of the Country.

\section{Introduction}

It is a well-recognized fact that Indian agriculture sector growth was completely sluggish or say even declined in the entire first half of the $20^{\text {th }}$ century (Blyn, 1966; Bardhan, 1984) during the British colonial period, whereas, this prototype was reversed post-independence (1947). The introduction of major food grains such as cereals and pulses registered a higher growth at 4.13 per cent during the first decade of independence i.e., 1951-52 to 1960-61 (Bhaduri, 1973; Kurosaki, 1999). The expansion of net area sown and an increase in crop yields were among the major contributors to the food grain growth, although the growth rate of agricultural sector declined during the same period. On the other hand, India's agricultural policy was mainly oriented to the institutional reforms such as land reforms and promotion of farming through cooperatives. Subsequently, India focussed on promoting industrialization, especially post the second five-year plan (1956-57 to 1960-61), while largely neglecting the agricultural sector.

During the mid-1960s, a consecutive two-year drought resulted in a large negative growth of agricultural sector, particularly in terms of food grain production and as a result, the country faced a serious shortage of food grains with many going without a single meal per day. Considering the contribution of the agricultural sector to GDP (about 50 per cent), its poor performance affected adversely the Indian economy as a whole, and even the political regime itself. As a result, the country was forced to import as many as 10 million tons of food grains (mainly wheat), from abroad for two succeeding years. This serious economic crisis forced the Government of India revisit its agricultural policy and accordingly, as a corrective measure, the government called for attention to technological innovations and even decided to import new agricultural technologies from abroad. And it was an opportune twist of fate for India that the mid 1960s was a phase when new seed-fertilizer technology dissemination started in the tropical developing world. In particular, it was fortunately found that wheat High Yield Varieties (HYVs) developed by CIMMYT in Mexico were found to be suitable to Indian climatic conditions, 
particularly North Indian states such as Punjab, Haryana, Uttar Pradesh and Madhya Pradesh. And as a result, the Government of India, was able to achieve food self-sufficiency within a short span of time, and today India is the highest food grain producer (285 million tons during 2018-19) in the world though with a few ups and downs during drought years. In this context, chemical fertilizer played a significant role in agricultural production, particularly NPK fertilizers.

The application of chemical fertilizers has considerably improved the quantity and quality in terms of plant parameters such as, increasing grain yield, leaf area, plant growth, photosynthesis and ultimately, main product and by-product yields. Thereby, chemical fertilizers have increased food availability, income and food security of the growing population of the nation today, but the impact of their long run application is a muchdebated issue among environmentalists. Among fertilizers, urea is an essential plant nutrient being a component of amino acids, nucleic acids, nucleotides, chlorophyll, enzymes, and hormones. Nitrogen $(\mathrm{N})$ is a major plant nutrient directly influencing crop growth and improving grain yield and grain quality through higher tilling, leaf area development, grain formation, grain filling, and protein synthesis. Urea is one of the most widely used sources of nitrogen fertilizer in the world.

Fertiliser consumption in India has been increasing since the beginning of Green Revolution to till date. Global fertilizer consumption is likely to cross above 201 million tons by 2019, which is about 25 per cent higher than the previous recorded year (in 2008). Asia as a whole is the highest consumer of fertilizer in the world, and depends on import of all three major nutrients. India ranks second in the world in terms of fertilizer consumption and third highest in terms of irrigated area (36.80\%). Presently, Indian fertilizer consumption has jumped from less than a million tonne in the mid-1960s to 27 million tons in 2019-20. Since the 1970s, urea has been a major source of nitrogen fertilizer, which is about 83 per cent of the total consumption. India has emerged as the second largest consumer of urea in the world.

The consumption of urea has slightly increased from 16.95 million tons in 2014-15 to 17.63 million tons in 2019-20. With a record urea production of 24.5 MT in 2015-16, its dominance as a major source of nitrogen fertilizer in India is likely to continue in the future as well (FAl, 2020). Further, fertilizer production recorded a mixed growth over the previous year. The production of Urea and NP/NPKs has declined while, that of DAP and SSP has recorded an increase. The production of Urea and NP/NPKs has declined by $0.5 \%$ and $3.5 \%$, respectively, during 2019 over 2018. Conversely, the production of DAP has recorded a sharp increase of 21.9 per cent, followed by a moderate increase of 2.8 per cent in the case of SSP during the same period (FAl, Quarterly Statistical Bulletin, 2020).

Per hectare consumption of NPK accounts for $128.02 \mathrm{~kg} / \mathrm{ha}$ in the India; moreover, NPK consumption ratio which was 6.10:2.46:1, during the period 2014-15 has increased to 7.23:2.9:1 in the year 2019, as against an ideal NPK (Nitrogen-Phosphorus-Potassium) consumption ratio of 4:2:1. This confirms that, a marginal improvement in the consumption of fertilizer ratios since 2014-15 due to the introduction of Neem Coated Urea by the Central Government with a view to improving soil health through checking an excessive use of urea, has made only a limited headway in the past five years. It shows that there is a further scope for changing the usage pattern of chemical fertilizers for improving soil health (Business line, 2019). Crops like, maize, wheat and rice (cereals) are the three main fertilizer-consuming crops with their consumption proportion being relatively the same (i.e., 14-16\% each) (Patrick Heffer, 2010; Fageria et.al., 2003a). On the other hand, a rise in 
fertilizer consumption over the years along with the adoption of HYVs and the expansion of groundwater irrigation facilities have resulted in highest food grain production in India. But the pattern of fertilizer use remains distorted with a growing imbalance in the use of chemical fertilizers, leading to nutrient deficiencies in soils, and thereby deficiency symptoms in plants. Further, there is a huge variation in fertilizer application across various states in India (Agostini et.al., 2010; Burns, 2006; Neeteson et.al, 1999; Rahn, 2002).

Considering all the pros and cons of agricultural production, input requirements and urea related subsidy burden, the government of India took a decision to introduce Neem Coated urea (NCU) by recognizing its potential benefits associated with NCU relative to NU. The Ministry of Agriculture and Farmers Welfare (MoA \& FW), Government of India, included NCU in the Fertilizer Control Order (FCO) since July 2004, and subsequently

made the production and distribution of NCU mandatory from $25^{\text {th }}$ May, 2015. Further, the Government of India launched a Soil Health Card Scheme (SHCS) on 19th February, 2015 with a focussed attention on improving the soil quality through a judicious use of fertilizers. Against this background, an attempt has been made by the authors to address the following objectives as part of a benchmark study regarding the impact of NCU on production and productivity of major crops, and its associated benefits to the farming community:

1. To study the trends in usage and pricing of Normal Urea and Neem Coated Urea.

2. To analyse the adoption behaviour of Neem Coated Urea farmers.

3. To analyse the impact of Neem Coated Urea on yield levels of major crops and income of farmers.

\section{Methodology}

\subsection{Sampling and Data Base}

In order to explore the impact of NCU on production, productivity and income across selected states of India, the study adopted a very relevant and detailed primary survey-based approach to the adoption of NCU. The study covered six very important cropping systems: Paddy, Tur, Sugarcane, Maize, Soybean and Jute. The states included are Assam, Bihar, Karnataka, Maharashtra, Madhya Pradesh and Punjab. To make the coverage exhaustive, a total of roughly 1200 sample farmers were surveyed. The reference period of the study was Kharif season for the agriculture year 2015. Both irrigated and rainfed crops accounting for the highest urea consumption in each of the selected states were considered for the study. For each crop, two districts were selected based on the area under the selected crop and their urea usage within the state. From each district, two taluks/tehsils were selected based on the same criterion. Within the selected taluks, two clusters comprising three to four villages per cluster were selected for conducting the survey.

A total of 50 farmers from each taluk were selected adding up to 100 farmers from each district. Households were selected randomly for assessing the NCU fertilizer use and its impact on crop production. Further, the households were post-classified in to two categories - NCU users and non-users (those using Normal Urea) mainly to examine the impact of NCU, as compared to NU. Whereas, an adequate care was taken to ensure that the selected crops were grown under chosen irrigated/un-irrigated conditions in the states. Thus, a total of 200 (NCU/ Normal Urea) farmers for each crop were interviewed. The primary data was collected by using a pretested structured questionnaire. An adequate care was taken in the selection of representative samples, based on the operational land holding size. The data related to production, import, consumption and prices of 
urea were also collected from various secondary sources such as, Directorate of economics and Statistics, Indiastat.com, Fertilizers Association of India, Department of Fertilizers (Ministry of Chemicals and Fertilizers), Government of India, and Department of agriculture, cooperation and farmers welfare etc. The details of sample selection are presented in Table 1.

\subsection{Analytical Tools and Techniques}

The information gathered from both primary and secondary sources were analysed, using tabular analysis. In addition, CAGR, exponential functions, partial budgeting frame work and paired unequal sample ' $\mathrm{t}$ ' test (between NCU and Non-NCU farmers for the year 2015) were also used for observing the significant differences between the two categories of farmers with respect to various indicators. A partial budgeting technique was employed for comparing the costs and returns related to NCU usage and the potential changes in crop production. Partial budget was divided into three main sections: (I) costs; (II) benefits; and (III) analysis. The analysis section included the net change in profits and break-even analysis (Benefit/Cost Ratio (BCR)). The possible changes occurring in the NCU intervention fell into four categories viz., added returns, reduced returns, added costs, and reduced costs. As part of a partial budgeting, an attempt has been made to present and discuss the comparative figures of costs incurred and returns realized related to NCU usage.

\section{Results And Discussion}

\subsection{Trends in all India Urea Production, Import, Consumption, and Prices}

To spot a pattern, trend analysis is the most common practice, hence, authors have adopted a trend analysis for understanding the growth pattern in terms of production, import, consumption, and prices of urea at the macro level. This technique is often used in extracting an underlying behavioural pattern based on a timeseries data, which remains partly or wholly hidden by noise. This method helps understand how, and why, things have changed are likely to change over time and an estimation has been done using a simple or multiple regression analysis. Urea has a high nitrogen content (46\%), can adapt to almost all types of land, and is widely used in the agricultural sector both as a fertilizer and animal feed additive and hence, urea is the most important nitrogenous fertilizer. Considering all these potential benefits, urea is the king of fertilizers.

The state-wise trends in consumption/sale of urea are presented in Table 2 and Figure 1. It is revealed from Table 2 that the consumption of urea has increased from 8542.92 thousand MTs in 2006-07 to 11376.76 thousand MTs in 2015-16 at the all India level with a growth rate of 2.94 per cent, and the growth is statistically significant at five per cent level. From among the selected states, Assam accounts for the highest growth rate $(5.50 \%)$, followed by Madhya Pradesh (5.10\%), Karnataka (2.92\%), Maharashtra (2.13\%), Punjab $(1.92 \%)$, and Bihar for the least (1.81\%), respectively. The percentage change over 2006-07 values to the existing values also reflects that the highest changeover has occurred in respect of Assam (102.10\%), followed by Madhya Pradesh (68.85\%), Karnataka (33.27\%), Punjab (30.15\%), Bihar (21.73\%) and Maharashtra $(15.86 \%)$. It is clear from the table that the changeover observed in consumption/ sales in the case of urea amounts to 33.17 per cent (Table 2), at the aggregate level.

\subsection{Socio-Economic Characteristics of the Sample Households}


The general characteristics of the overall sample farmers are shown in Table 3. The table reveals wide variations in the socio-economic characteristics of farmers across the sample states in relation to different crops. The average age of sample farmers across all the states works out to 46 years with a majority of them being male respondents. On an average, the sample farmer family consists of seven members, out of which, three have been engaged in farming for last 24 years. These characteristics are relatively common for all the respondents growing different crops and across States. Coming to literacy level, a majority (28\%) of them have completed Pre-University and above, followed by primary schooling $(23 \%)$, higher primary $(21 \%)$ and matriculation (16\%); however, about 12 per cent of them are found illiterates. Across crops, a majority ( $>60 \%)$ of the paddy, sugarcane and maize farmers have completed matriculation and above, while in respect of tur, soybean and jute, more than half of the farmers have studied up to higher primary level. At the aggregate, a majority of the sample farmers belong to general category (51\%), followed by Other Backward Classes (OBCs) $(29 \%)$, Scheduled Castes (11\%) and Scheduled Tribes (7\%) while in the case of maize, more than half of the farmers (58\%) belong to OBC category. The proportion remains relatively the same in respect of all the crops.

\subsection{Average Size of Operational Landholding of the Sample Farmers}

The details of operational land holdings of the sample farmers are presented in Table 4. The table reveals that the average net operational area in the study region is comparatively higher in the case of sugarcane farmers (12.6 acres), followed by paddy farmers (10.80 acres), and tur farmers (10.34 acres). The least net operational area (6.37 acres) is observed for jute farmers. While in respect of the remaining cases such as soybean and maize, the net operational area works out to less than 10 acres. As usual, the highest operational land rests with large farmers only, in respect of all the sample crops, however, it is found to be as high as 27 acres in the case of sugarcane farmers, followed by maize (20.80 acre) and tur farmers (19.25 acres). Overall, a substantial proportion of the operational area is accounted for land owners ( $>7$ acres) across all crops. Interestingly, the leased-in area seems to be highest in respect of paddy crop only ( 2.25 acres). Whereas the proportion is less than an acre/ household in respect of the rest of the crops. On the contrary, the leased-out area constitutes less than an acre across crops. However, it is highest ( 0.75 acre) in respect of maize crop in Bihar. Similarly, the proportion of uncultivated or fallow land is found to be negligible across sample farmers in the study area. With regard to irrigation, in addition to the irrigated crops such as paddy and sugarcane, soybean also accounts for a major area ( $>90 \%$ each) under irrigation from among the sample crops, and the remaining area comes under rainfed conditions. Additionally, the area under maize and jute crops covered under irrigation also constitutes more than 72 per cent. Whereas, tur is majorly grown under rainfed conditions both in the states of Karnataka and Maharashtra and hence, the proportion of rainfed area constitutes more $(71 \%)$ in the case of tur crop. However, about 29 per cent of the farmers grow tur under irrigated conditions as well. It is noted that across categories of farmers, a higher proportion of irrigated land is accounted for by small farmers, followed by medium, and large farmers in respect of almost all the irrigated crops.

The average rental value of leased-in land amounts to a maximum of Rs.15,231/ acre for paddy, followed by soybean (Rs.13,639/ acre) and jute (Rs. 5,696/ acre), while it is less than Rs. 5,000/ acre in the case of tur and sugarcane crops. At the same time, across categories, the rental value of leased-in land is highest (Rs.18,507/acre) for small farmers, followed by medium farmers (Rs. 14,810/ acre), in respect of paddy, whereas, it is medium farmers (Rs. 14,417/acre), followed by small farmers (Rs. 13,300/ acre) in the case of soybean crop. Relatively, the same situation prevails across other crops. On the other hand, the rental value of 
leased-out land is slightly less than the value of leased-in land in the sample area. Similar to the rental value of leased-in land, the leased-out land value is highest in respect of paddy (Rs. 11,916/ acre), followed by soybean (Rs. 11,286/ acre). However, the leased-out land value of small farmers in the case of paddy is highest (Rs. 20,294 / acre), as compared to the rental values of leased-in and leased-out land across all crops. Interestingly, no sample farmers are found engaged in leasing-in and leasing-out activities, in respect of maize and sugarcane crops, respectively.

\subsection{Cropping Pattern Adopted by the Sample Farmers in the Study Area}

Given the land resources, agricultural production and profitability can be increased through adoption of a scientific cropping pattern. The adoption of technology in respect of cropping system depends on many factors such as physical and socio-economic resources, available or made available, at a time, when they are needed most. In this background, the cropping pattern followed by different categories of farm households has been analyzed and results presented in Table 5.

Paddy-farmers across the states grow cereals as the major crops with a share of 68.95 per cent in the gross cropped area, followed by commercial crops (9.09\%), horticultural and fodder crops (12.59\%). Whereas, tur farmers across the states grow pulses as the major crops with a share of 35.74 per cent in the gross cropped area, followed by oilseed (30.56\%), horticultural and fodder crops (15.56\%), cereal crops (9.20\%) and oilseed crops (8.33\%). It reveals that the location-specific and farm-based cropping patterns have to be evolved with a due consideration given to the vital determinants such as land, topography, water availability, intensity and duration of sunlight, labour availability, cash or credit, power source and market demand. Among different crops cultivated by sugarcane farm households, commercial crops are the major crops with a share of 61.93 per cent in the gross cropped area, followed by cereals, oilseeds and horticulture and fodder crops, with a share of about 12 per cent each in the gross cropped area. Further, the small size of land holding does not prevent these farmers from growing perennial crops.

Maize-farmers across the states grow crops like paddy, maize and soybean. It is evident from the table that cereal crops account for as high as 86.91 per cent of the gross cropped area, followed by oilseeds (about $12 \%)$. Whereas, soybean farmers across the states grow crops like paddy, soybean and cotton as their major crops. Among them, oilseed crop alone accounts for as high as 76.94 per cent of the cropped area, followed by cotton as a commercial crop (18.82\%) and the least (4.23\%) in the case of cereal crops. It is a good practice followed by soybean farmers as part of being risk-averse and also from the view point of generating income from other sources such as dairy-farming and cultivation of commercial crops such as pulses, cotton and cereals. However, in the case of jute farmers, jute apart, other crops are grown only for their subsistence. The cropping pattern is dominated by jute and paddy, accounting for around 74.79 per cent and 18.94 per cent of the gross cropped area, respectively. Further, jute farmers are found to have devoted about 6.27 per cent of GCA for vegetable production.

\subsection{Impact of NCU on Production and Marketing of Reference Crops}

During the reference period (Kharif 2015), both NU and NCU were available in the market across the study area before the government made mandatory the production (100\%) and distribution of NCU throughout the country. Therefore, an effort was made by the study to compare the impact of NU and NCU on the production 
and productivity of reference crops across states in India. The details of the impact of NCU on production and marketing of reference crops are presented in Table 6. A perusal of the table reveals that out of the sample crops, the average main product yield of soybean was highest in the case of NCU users (5.32 quintals/acre), as compared to NU users (3.86 quintals/acre), accounting for a statistically significant increase in the yield levels at 37.82 per cent, followed by tur (33.68\%) and maize (7.99\%). This is due to the presence of neem content in urea, which slows down the release of nitrogen, as a result, ' $N$ ' is available to plants for a longer period, as compared to NU and concomitantly reduces the frequency of application and consumption of urea fertilizer. These results also conform to the study findings of John et.al., (1989), who found a significant increase in grain yield of rice based on their successive field experiments. Similarly, in terms of by-product yield, the increase in yield amounts to 23.31 per cent, as compared to that of tur crop in the context of NU application, followed by soybean (11.14\%). This increase in yield is found to be statistically significant. In the cases of paddy and sugarcane, the prices of the main product appear to be relatively the same with regard to NCU and NU. The per cent change over post NCU application in place of NU varies within two per cent, whereas, in respect of tur, jute, maize and soybean crops, the prices seem to have decreased to the tune of $2.38,0.53,2.50$ and 12.35 per cent, respectively, which could be due to market imperfections. Similarly, in the case of byproduct price, the per cent change in respect of NCU, as compared to NU, amounts to 16.57 per cent in the case of sugarcane, followed by soybean $(9.81 \%)$ and paddy $(8.98 \%)$. The increase in the price of sugarcane byproduct from Rs.356/ bundle (without NCU) to Rs. 415/ bundle (with NCU) might be attributed to the application of NCU, in addition to many other factors. Further, a majority of the farmers also have reported an increase in the quality of both the main product and by-product yields, post NCU application. With respect to statistical significance, most of the prices of reference crops appear to be non-significant. Depending upon the prices of both the main product and by-product, the value of main product and by-product of tur crop show an increase of 32.23 per cent and 38.15 per cent, respectively, post the adoption of NCU in place of NU at the aggregate level, and is found statistically significant at one per cent level for the values of main product and non-significant for by-product.

\subsection{Impact of NCU Use on the Component-Wise Cost of Reference Crops}

The details of the impact of NCU on the input costs of reference crops across the sample states are presented in Table 7. To assess the impact of NCU usage on input costs, parameters such as the cost of pest and disease control, the cost of weed management, the cost of NCU or NU, and the cost of other fertilizers were considered. Table 7 reveals a comparative picture of the input costs of NCU and NU using farmers. A perusal of the table reveals that the total cost of the selected inputs has increased for NCU users (Rs.3,833/acre), as compared to NU users (Rs.2,192/acre), to the extent of 74.86 per cent in respect of tur crop, followed by maize (14.30\%) and paddy (4.48\%), while in contrast, crops like jute and soybean show a decline in per cent change, at the aggregate level. Whereas, the cost illustrates a decreasing scenario in respect of all the parameters, excepting the cost of other fertilizers for paddy and soybean farmers, respectively. An increasing trend in the cost of pest and diseases control, weed management, and other fertilizers can be seen in respect of tur $(6.65 \%$ $, 40.24 \%, 67.72 \%)$ and sugarcane $(22.49 \%, 0.49 \%, 4.83 \%)$, respectively. In terms of disparity, the decreasing trend in the cost of NCU/ NU works out to $0.19,16.78,15.34$, and 3.50 per cent for paddy, jute, sugarcane and soybean, respectively.

\subsection{Economic Feasibility of NCU Use for Reference Crops Using Partial Budgeting Technique}


An economic feasibility analysis of NCU use, often with and without NCU, approach has been used for identifying and assessing the costs and benefits as part of an evaluation of the current situation, more meaningfully. The difference between the costs and benefits is the net incremental benefit arising from NCU usage. However, a before and after approach has not been used in this framework on account of changes in production that would have occurred due to regular developments, along with NCU usage. While assessing the benefits and costs of NCU usage, only incremental net benefits need to be considered, with the reduced benefits treated as costs. The benefits foregone need to be taken as a cost component of NCU usage. Thereby, only incremental value could be attributed to NCU. Hence, a partial budget technique has been used for assessing the incremental income based on a small change in farm business post NCU application. In the present article, a partial budgeting framework has been estimated for variables such as additional income, reduced costs, reduced income and additional costs, following a small change in NCU use vis-a-vis NU. The budget indicates whether the change has increased/ decreased/ no change in the net income with the adoption of NCU. Also, the partial budget compares both the positive and negative effects of a change with $\mathrm{NCU}$ use in relation to $\mathrm{NU}$, or an incremental income accruing from reference crops.

The impact of NCU, based on a partial budgeting technique, considering added and reduced costs with NCU application for reference crops is estimated and presented in Table 8. It can be seen from the table that there is a positive impact of the economic feasibility of NCU use on reference crops. The variables considered for estimating a partial budgeting framework in the study include the cost of pest and disease control, cost of weed management, cost of NCU/NU, and the cost of other fertilizers. In the table, only cost and returns are highlighted. At the aggregate level, the added costs with NCU application appear to be as high as Rs. 1,685.87 per acre in the case of maize, followed by tur (Rs. 1,300/acre) and soybean (Rs. 1,141/acre), respectively.

It is exceptional to note that the reduced returns have been reported highest in the case of sugarcane (Rs. 5,749 /acre), followed by soybean (Rs. 3,942/acre) and maize (Rs. 1,965/acre). Instead, added returns both in terms of the main product and by-product yields are noticed in respect of tur (Rs. 16,558 per acre) and paddy producers (Rs. 2,943/acre) only because of the adoption of NCU in place of NU. Whereas, reduced costs with NCU application are observed for almost all the sample crops with varying amounts. However, the reduced costs are found to be highest in the case of paddy (Rs. 227/acre), followed by sugarcane (Rs. 149/acre) and maize (Rs. 84/acre). This is the positive impact of NCU adoption in lieu of NU, in addition to other favourable factors. Using the same information, the benefit-cost ratio has been arrived at and presented in the same table. It is very much interesting to note that the $\mathrm{BC}$ ratio is more than 10 in respect of tur and sugarcane crops, meaning that, for every one rupee of investment on NCU application, there has been a rise in returns to the extent of Rs. 10. As regards paddy and soybean, the ratio works out to more than three per cent, while it is least $(<1 \%)$ in the case of maize. These results illustrate that the application of NCU has had a positive impact in terms of both increased yield and income due to reduced costs for the farmers.

\subsection{Diversion of Urea for Other than Agricultural Purposes}

Based on the study, what can be inferred is that a majority of the farmers have used normal urea in smaller proportions as a feed to cattle and fishes, mixing with milk to enhance fat content, distilling local alcohol etc. However, the usage of urea has been completely stopped, post the introduction of NCU. 


\section{Conclusions}

Recognizing the various positive benefits of NCU and its impact on the environment, the Union Government of India has made mandatory the production and distribution of NCU (100\%) across the country from May 2015. The aim of the policy is to control an excess use of urea in agriculture, besides preventing the diversion of subsidized urea towards industrial purposes. The results reveal that the aim of the policy seems to have materialized, as the diversion of urea has completely stopped post the introduction of NCU. In addition, both the main product and by-product yield levels of all the reference crops have increased, and farmers have reaped the positive externalities of NCU in terms of increased outputs, reduced costs (in terms of pest and disease control), and thereby increased returns. These benefits might not be related to NCU usage alone, as some other favourable reasons might have contributed to the same as well. However, the usage of NCU relative to NU has not been impressive due to the ignorance of farmers about the potential benefits of NCU over NU and its application. Hence, there is a need for spreading awareness among farmers regarding the NCU usage and its benefits through trainings, organizing demonstrations etc. It is very difficult to realize all the potential benefits associated NCU use within a limited period (as the study was limited to Kharif 2015). Hence, this can be treated as a baseline survey, which can be repeated after a few years so as to have a better picture of NCU. Nevertheless, any efforts towards reducing the cost of production and increasing the returns to the farming community, needs to be promoted to realise our Prime Minister's dream of doubling the farmers' income by 2022.

\section{Declarations}

Authors would like to express heartfelt thanks to all the officials of Centre and State/s (Ministry and Department of Agriculture), and all the participating AERCs and their team, for their immense support, active involvement, and cooperation, during the period of study.

The authors declare no competing interests.

\section{References}

Agostini, F., Tei, F., Silgram, M., Farneselli, M., Benincasa, P., \& Aller, M. F (2010): “Decreasing nitrate leaching in vegetable crops with better $\mathrm{N}$ management. In Genetic engineering, biofertilisation, soil quality and organic farming," Springer (pp. 147-200).

Biswas, A. K., and Subba Rao, A (2015): “Enhancing Nitrogen Use Efficiency - Challenges and Options,". A paper submitted to Ministry of Agriculture, Government of India by the Indian Institute for Soil Science (IISS), Bhopal.

Bhaduri, A (1973): "A study in agricultural backwardness under semi-feudalism", The economic journal, 83(329), 120-137.

Blyn, G (1966): "Agricultural trends in India,1891-1947, output, availability, and productivity. University of Pennsylvania Press, Book 374 pages, 
Burns, I.G (2006): "Assessing N fertiliser requirements and the reliability of different recommendation system," Acta Hort. 700:35-48.

Dordrecht and Bardhan, P.K (1984): "Land, Labor and Rural Poverty: Essays in Development Economics," Oxford University Press.

Fageria, N.K., and Baligar, V.C (2003a): "Fertility management of tropical acid soils for sustainable crop production," In Handbook of Soil Acidity, Z. Rengel, Ed., pp. 359-385. Marcel Dekker, New York.

FAO (2005): “Fertilizer Use by Crop in India," Land and Plant Nutrition Management Service, Land and Water Development Division, Food and Agriculture Organization, United Nations, Rome.

John, P.S., Buresh, R.J., Pandey, R.K., Prasad, R. and Chua, T.T (1989): “Nitrogen-15 balances for urea and neem coated urea applied to lowland rice following two cowpea cropping systems," Plant and Soil journal, 120(2), pp.233-241.

Kurosaki, T (1999: "Agriculture in India and Pakistan- Productivity and Crop Mix", Economic and Political Weekly, 34 (52), December 25, A160-A168.

Neeteson, J.J., Booij, R., Whitmore, A.P (1999) "A review on sustainable nitrogen management in intensive vegetable production systems," Acta Hort.506:17-26.

Heffer, P (2009): "Assessment of fertilizer use by crop at the global level," http://www. Fertilizer, org, 2006/072007/08.

Singh S and Y.S Shivay (2003): "Coating of Prilled Urea with Eco-friendly Neem (Azadirachta indica A. Juss.) formulations for efficient nitrogen use in hybrid rice," Acta Agronomica Hungarica, 51(1), pp. 53-59.

\section{Tables}

Table 1: State wise, crop coverage and sample size 


\begin{tabular}{|c|c|c|c|c|}
\hline SI. No./ Region & Crops & Irrigated/un irrigated & Sample Farmers & Total \\
\hline South & \multicolumn{4}{|c|}{ Karnataka } \\
\hline 1 & Paddy & Irrigated & 200 & \multirow[t]{2}{*}{400} \\
\hline 2 & Tur & Un-Irrigated & 200 & \\
\hline West & \multicolumn{4}{|c|}{ Maharashtra } \\
\hline 3 & Sugarcane & Irrigated & 200 & \multirow[t]{2}{*}{400} \\
\hline 4 & Tur & Un-Irrigated & 200 & \\
\hline Central & \multicolumn{4}{|c|}{ Madhya Pradesh } \\
\hline 5 & Paddy & Irrigated & 200 & \multirow[t]{2}{*}{400} \\
\hline 6 & Soybean & Un-Irrigated & 200 & \\
\hline East & \multicolumn{4}{|c|}{ Bihar } \\
\hline 7 & Paddy & Irrigated & 200 & \multirow[t]{2}{*}{400} \\
\hline 8 & Maize & Un-Irrigated & 200 & \\
\hline North & \multicolumn{4}{|l|}{ Punjab } \\
\hline 9 & Paddy & Irrigated & 200 & 200 \\
\hline North-east & \multicolumn{4}{|c|}{ Assam } \\
\hline 10 & Paddy & Irrigated & 200 & \multirow[t]{2}{*}{400} \\
\hline 11 & Jute & Un-Irrigated & 200 & \\
\hline \multirow{2}{*}{ All India } & & Irrigated & 1200 & \multirow{2}{*}{2200} \\
\hline & & Un-Irrigated & 1000 & \\
\hline
\end{tabular}

Source: Primary data

Table 2: Trends in all India urea production, import, consumption and prices (lakh MT)

\begin{tabular}{|c|c|c|c|c|c|c|c|}
\hline Years & Assam & Bihar & Karnataka & Maharashtra & MP & Punjab & All India \\
\hline 2006 & 194.10 & 1598.10 & 1097.58 & 1985.00 & 1297.00 & 2371.14 & 8542.92 \\
\hline 2007 & 195.41 & 1851.72 & 1253.63 & 2131.00 & 1425.00 & 2646.44 & 9503.20 \\
\hline 2008 & 223.48 & 1794.82 & 1281.99 & 2258.00 & 1371.00 & 2576.90 & 9506.19 \\
\hline 2009 & 251.31 & 1701.11 & 1377.07 & 2289.00 & 1603.00 & 2445.76 & 9667.25 \\
\hline 2010 & 256.61 & 1691.21 & 1427.71 & 2538.00 & 1669.00 & 2720.44 & 10302.97 \\
\hline 2011 & 304.61 & 1811.51 & 1444.80 & 2481.00 & 1788.00 & 2825.70 & 10655.62 \\
\hline 2012 & 278.93 & 2095.96 & 1446.32 & 2332.00 & 1856.00 & 2842.97 & 10852.18 \\
\hline 2013 & 281.51 & 1870.64 & 1479.20 & 2655.00 & 2224.00 & 2619.32 & 11129.67 \\
\hline 2014 & 299.53 & 1940.41 & 1532.60 & 2572.00 & 2017.00 & 2734.26 & 11095.80 \\
\hline 2015 & 392.39 & 1945.52 & 1462.80 & 2300.00 & 2190.00 & 3086.05 & 11376.76 \\
\hline CAGR & $5.50 * *$ & $1.81 * *$ & $2.92 * * *$ & $2.13 * * *$ & $5.10 * * *$ & $1.92 * *$ & $2.94 * * *$ \\
\hline \% change over from 2006-07 to & 102.10 & 21.73 & 33.27 & 15.86 & 68.85 & 30.15 & 33.17 \\
\hline $2015-16$ & & & & & & & \\
\hline
\end{tabular}

Note: * Indicates percentage change over 2006-07 to 2015-16 
Table 3: Crop wise socio-economic characteristics of the sample households

\begin{tabular}{|c|c|c|c|c|c|c|c|c|}
\hline $\begin{array}{l}. \\
0 .\end{array}$ & Particulars & Paddy & Tur & Sugarcane & Maize & soybean & Jute & Overall \\
\hline & $\begin{array}{l}\text { Age of respondents } \\
\text { (Years) }\end{array}$ & 46 & 48 & 47 & 49 & 45 & 44 & 46 \\
\hline & Male respondents (\%) & 99.30 & 98.00 & 99.00 & 100.00 & 95.00 & 100.00 & 98.50 \\
\hline & $\begin{array}{l}\text { Family members } \\
\text { engaged in farming } \\
\text { (No.) }\end{array}$ & 3 & 3 & 3 & 2 & 4 & 2 & 3 \\
\hline & $\begin{array}{l}\text { Experience in farming } \\
\text { (years) }\end{array}$ & 23 & 27 & 28 & 19 & 25 & 22 & 24 \\
\hline & Family size (No.) & 7 & 7 & 7 & 7 & 7 & 6 & 7 \\
\hline & \multicolumn{8}{|c|}{ Literacy level (\% farmers) } \\
\hline & Illiterates & 9.40 & 12.25 & 2.00 & - & 25.50 & 20.50 & 11.60 \\
\hline & Primary (1 to 4 ) & 8.20 & 29.00 & 7.50 & 21.50 & 23.50 & 48.50 & 23.03 \\
\hline t. & $\begin{array}{l}\text { Higher primary (5 to } \\
\text { 9) }\end{array}$ & 19.10 & 15.50 & 19.00 & 18.00 & 38.00 & 17.00 & 21.10 \\
\hline & Matriculation (10) & 19.70 & 19.75 & 26.50 & 19.50 & 06.50 & 6.00 & 16.32 \\
\hline & $\begin{array}{l}\text { Pre-University }(10+2) \\
\& \text { above }\end{array}$ & 43.60 & 23.50 & 45.00 & 41.00 & 06.50 & 8.00 & 27.95 \\
\hline & \multicolumn{8}{|l|}{ Caste (\% farmers) } \\
\hline & General & 51.90 & 43.75 & 72.50 & 25.50 & 11.00 & 98.90 & 50.59 \\
\hline & $\mathrm{OBC}$ & 37.70 & 34.25 & 14.00 & 58.50 & 30.00 & 01.10 & 29.25 \\
\hline i & $\mathrm{SC}$ & 5.80 & 8.50 & 4.00 & 8.50 & 37.50 & - & 10.71 \\
\hline & ST & 4.60 & 6.25 & 0.50 & 7.50 & 21.50 & - & 6.75 \\
\hline & Others & - & 7.25 & 9.00 & - & - & - & 2.70 \\
\hline & $\begin{array}{l}\text { Net Operational } \\
\text { Area(Acres) }\end{array}$ & & & & & & & \\
\hline
\end{tabular}

e: Selected study sates, Assam, Bihar, Karnataka, Maharashtra, Madhya Pradesh and Punjab

Table 4 Crop wise, average size of operational landholding of the sample farmers (Acres)

\begin{tabular}{|c|c|c|c|c|c|c|c|c|}
\hline $\begin{array}{l}\text { SI. } \\
\text { No }\end{array}$ & Particulars & Paddy & Tur & Sugarcane & Maize & soybean & Jute & Averages \\
\hline 1 & Own land & 8.81 & 10.41 & 12.78 & 10.42 & 7.72 & 7.07 & 9.54 \\
\hline 2 & Uncultivated/ Fallow & 0.11 & 0.28 & 0.19 & 0.02 & 0.1 & 0.23 & 0.16 \\
\hline 3 & Leased-in & 2.25 & 0.21 & 0.06 & - & 0.58 & 0.21 & 0.66 \\
\hline 4 & Leased-out & 0.53 & - & - & 0.75 & 0.01 & 0.68 & 0.49 \\
\hline 5 & $\begin{array}{l}\text { Net Operational Area } \\
(1-2+3-4)\end{array}$ & 10.80 & 10.34 & 12.66 & 9.70 & 8.19 & 6.37 & 9.68 \\
\hline 6 & $\%$ of irrigated land & 90.22 & 29.35 & 90.21 & 78.54 & 93.59 & 80.79 & 77.12 \\
\hline 7 & $\%$ of un irrigated land & 9.77 & 70.65 & 9.79 & 21.45 & 6.41 & 19.21 & 22.88 \\
\hline 8 & $\begin{array}{l}\text { Rental value of } \\
\text { leased-in land } \\
\text { (Rs/Acre) }\end{array}$ & 15231 & 3755 & 4080 & 5412 & 13639 & 5696 & 7968.83 \\
\hline 9 & $\begin{array}{l}\text { Rental value of } \\
\text { leased-out land } \\
\text { (Rs/Acre) }\end{array}$ & 11917 & 1917 & 25000 & 5973 & 11286 & 8211 & 10717.33 \\
\hline
\end{tabular}


Note: Selected study sates, Assam, Bihar, Karnataka, Maharashtra, Madhya Pradesh and Punjab

Table 5 Crop wise, Cropping Pattern adopted by the sample farmers in the study area (\%)

\begin{tabular}{|c|c|c|c|c|c|c|c|}
\hline SI. No & Particulars & Paddy & Tur & Sugarcane & Maize & soybean & Jute \\
\hline I & Cereals & & & & & & \\
\hline 1. & Paddy & 68.95 & 9.20 & 12.90 & 19.01 & 4.23 & 18.94 \\
\hline 2. & Maize & 5.34 & & & 67.90 & & \\
\hline \multirow[t]{2}{*}{3.} & Basmati & 4.72 & & & & & \\
\hline & Sub Total & 79.01 & 9.20 & 12.90 & 86.91 & 4.23 & 18.94 \\
\hline II & Pulses & & & & & & \\
\hline 4. & Redgram (Tur) & & 33.25 & 1.07 & & & \\
\hline 5. & Pulses (other than tur) & & 2.49 & & & & \\
\hline 6. & Sub Total & 0.00 & 35.74 & 1.07 & 0.00 & 0.00 & 0.00 \\
\hline III & Oilseeds & & & & & & \\
\hline 7. & Soya bean & & 20.00 & 12.03 & 12.93 & 76.94 & \\
\hline \multirow[t]{2}{*}{8.} & Other Oilseeds & & 10.56 & & & & \\
\hline & Sub Total & 0.00 & 30.56 & 12.03 & 12.93 & 76.94 & 0.00 \\
\hline IV & Commercial Crops & & & & & & \\
\hline 9. & Sugarcane & 2.07 & & 59.40 & & & \\
\hline 10. & Cotton & 7.02 & 8.33 & 2.53 & & 18.82 & \\
\hline \multirow[t]{2}{*}{11.} & Jute & & & & & & 74.79 \\
\hline & Sub Total & 9.09 & 8.33 & 61.93 & 0.00 & 18.82 & 74.79 \\
\hline $\mathbf{V}$ & \multicolumn{7}{|c|}{ Horticultural and fodder crops } \\
\hline 12. & Onion & & 3.56 & 6.02 & & & \\
\hline 13. & Vegetables & 1.14 & & 6.00 & & & 6.27 \\
\hline 14. & Fodder & 7.23 & & & & & \\
\hline \multirow[t]{2}{*}{15.} & Others & 4.22 & 12.00 & & & & \\
\hline & Sub Total & 12.59 & 15.56 & 12.02 & 0.00 & 0.00 & 6.27 \\
\hline VI & Gross cropped area (\%) & 101 & 99 & 100 & 100 & 100 & 100 \\
\hline
\end{tabular}

Table 6: Impact of NCU on production and marketing of reference crops (Quintals/Acre) 


\begin{tabular}{|c|c|c|c|c|c|c|c|c|c|c|c|c|}
\hline \multirow[t]{2}{*}{ Particulars } & \multicolumn{2}{|c|}{ Paddy } & \multicolumn{2}{|c|}{ Tur } & \multicolumn{2}{|c|}{ Jute } & \multicolumn{2}{|c|}{ Maize } & \multicolumn{2}{|c|}{ Sugarcane } & \multicolumn{2}{|c|}{ Soybean } \\
\hline & NCU & NU & NCU & NU & NCU & NU & NCU & NU & NCU & NU & NCU & NU \\
\hline $\begin{array}{l}\text { Main } \\
\text { product } \\
\text { yield } \\
\text { (quintal) }\end{array}$ & 22.52 & $\begin{array}{c}20.90^{* * *} \\
(7.75)\end{array}$ & 3.5 & $\begin{array}{l}2.62 \mathrm{Ns} \\
(33.58)\end{array}$ & 8.86 & $\begin{array}{c}8.60 * * * \\
(3.02)\end{array}$ & 25.25 & $\begin{array}{c}23.38^{* *} \\
(7.99)\end{array}$ & 539 & $\begin{array}{c}513^{* * *} \\
(5.06)\end{array}$ & 5.32 & $\begin{array}{l}3.86^{* * *} \\
(37.82)\end{array}$ \\
\hline $\begin{array}{l}\text { By-product } \\
\text { Yield } \\
\text { (quintal) }\end{array}$ & 32.41 & $\begin{array}{c}31.59 \mathrm{Ns} \\
(2.59)\end{array}$ & 2.38 & $\begin{array}{c}1.93 * \\
(23.31)\end{array}$ & 3.10 & $\begin{array}{c}3.10 \mathrm{NS} \\
(0.00)\end{array}$ & 16.32 & $\begin{array}{c}16.31 \mathrm{Ns} \\
(0.06)\end{array}$ & 0.8 & $\begin{array}{l}0.8 \mathrm{Ns} \\
(0.00)\end{array}$ & 7.98 & $\begin{array}{c}7.18^{*} \\
(11.14)\end{array}$ \\
\hline $\begin{array}{l}\text { Price of } \\
\text { main } \\
\text { product } \\
\text { (Rs/ } \\
\text { quintal) }\end{array}$ & 1373 & $\begin{array}{c}1365^{* * *} \\
(0.58)\end{array}$ & 8217 & $\begin{array}{c}8418 \mathrm{Ns} \\
(-2.38)\end{array}$ & 2044 & $\begin{array}{c}2055 \mathrm{Ns} \\
(-0.53)\end{array}$ & 1049 & $\begin{array}{c}1076 \mathrm{Ns} \\
(-2.50)\end{array}$ & 221 & $\begin{array}{l}216 * * \\
(2.31)\end{array}$ & 3151 & $\begin{array}{c}3595 * * \\
(-12.35)\end{array}$ \\
\hline $\begin{array}{l}\text { Price of } \\
\text { by-product } \\
\text { (Rs/ } \\
\text { quintal) }\end{array}$ & 182 & $\begin{array}{l}167 * * \\
(8.98)\end{array}$ & 431 & $\begin{array}{l}489 * * * \\
(-11.86)\end{array}$ & 250 & $\begin{array}{c}250 \mathrm{Ns} \\
(0.00)\end{array}$ & 152 & $\begin{array}{l}145 \mathrm{Ns} \\
(4.82)\end{array}$ & 415 & $\begin{array}{l}356 \mathrm{Ns} \\
(16.57)\end{array}$ & 179 & $\begin{array}{l}163^{* *} \\
(9.81)\end{array}$ \\
\hline $\begin{array}{l}\text { Value of } \\
\text { main } \\
\text { product } \\
\text { (Rs) }\end{array}$ & 31740 & $\begin{array}{c}29326 \mathrm{Ns} \\
(8.23)\end{array}$ & 29645 & $\begin{array}{c}22419 \mathrm{Ns} \\
(32.23)\end{array}$ & 18110 & $\begin{array}{c}17673^{* *} \\
(2.47)\end{array}$ & 26487 & $\begin{array}{c}25157 * * \\
(5.28)\end{array}$ & 119231 & $\begin{array}{c}110912 \\
* * \\
(7.50)\end{array}$ & 16763 & $\begin{array}{c}13877 * * * \\
(20.80)\end{array}$ \\
\hline $\begin{array}{l}\text { Value of } \\
\text { by-product } \\
\text { (Rs) }\end{array}$ & 4094 & $\begin{array}{c}3305 \mathrm{Ns} \\
(23.87)\end{array}$ & 1032 & $\begin{array}{l}747 * * * \\
(38.15)\end{array}$ & 775 & $\begin{array}{c}775 \mathrm{NS} \\
(0.00)\end{array}$ & 2481 & $\begin{array}{l}2365^{*} \\
(4.90)\end{array}$ & 343 & $\begin{array}{l}297 \mathrm{NS} \\
(15.48)\end{array}$ & 1428 & $\begin{array}{c}1170 * * * \\
(22.05)\end{array}$ \\
\hline
\end{tabular}

Note: ***,** \& * indicate 1, 5 and 10 per cent levels of Significance, respectively; Figures in parentheses indicate percentage change

Table 7: Impact of NCU use on the component-wise cost of reference crops

(Values in Rs/Acre)

\begin{tabular}{|c|c|c|c|c|c|c|c|c|c|c|c|c|}
\hline \multirow[t]{2}{*}{ Particulars } & \multicolumn{2}{|c|}{ Paddy } & \multicolumn{2}{|c|}{ Tur } & \multicolumn{2}{|c|}{ Jute } & \multicolumn{2}{|c|}{ Maize } & \multicolumn{2}{|c|}{ Sugarcane } & \multicolumn{2}{|c|}{ Soybean } \\
\hline & NCU & NU & NCU & NU & NCU & NU & NCU & $\mathrm{NU}$ & NCU & NU & $\mathrm{NCU}$ & NU \\
\hline $\begin{array}{l}\text { Cost of pest } \\
\text { and disease } \\
\text { control }\end{array}$ & 1362 & $\begin{array}{l}1453^{* *} \\
(-6.26)\end{array}$ & 1090 & $\begin{array}{c}1022^{* * *} \\
(6.65)\end{array}$ & 127 & $\begin{array}{l}123^{* *} \\
(3.25)\end{array}$ & 268 & $\begin{array}{c}344 \mathrm{Ns} \\
(-22.09)\end{array}$ & 501 & $\begin{array}{l}409 \mathrm{Ns} \\
(22.49)\end{array}$ & 689 & $\begin{array}{c}817^{* *} \\
(-15.66)\end{array}$ \\
\hline $\begin{array}{l}\text { Cost of weed } \\
\text { management }\end{array}$ & 569 & $\begin{array}{l}601 * * * \\
(-5.32)\end{array}$ & 453 & $\begin{array}{c}323^{* * *} \\
(40.24)\end{array}$ & 1211 & $\begin{array}{c}1212 \mathrm{Ns} \\
(-0.08)\end{array}$ & 213 & $\begin{array}{l}221 \mathrm{Ns} \\
(-3.61)\end{array}$ & 607 & $\begin{array}{c}604 \mathrm{NS} \\
(0.49)\end{array}$ & 443 & $\begin{array}{c}486^{*} \\
(-8.84)\end{array}$ \\
\hline $\begin{array}{l}\text { Cost of NCU } \\
\text { / Normal } \\
\text { Urea }\end{array}$ & 510 & $\begin{array}{l}511 * * * \\
(-0.19)\end{array}$ & 279 & $\begin{array}{c}233 \mathrm{Ns} \\
(19.74)\end{array}$ & 243 & $\begin{array}{c}292^{* * *} \\
(-16.78)\end{array}$ & 848 & $\begin{array}{l}807^{* *} \\
(5.08)\end{array}$ & 1451 & $\begin{array}{c}1714 \\
* * * \\
(-15.34)\end{array}$ & 110 & $\begin{array}{l}114^{* * *} \\
(-3.50)\end{array}$ \\
\hline $\begin{array}{l}\text { Cost of other } \\
\text { fertilizers }\end{array}$ & 5666 & $\begin{array}{l}5194^{*} \\
(9.08)\end{array}$ & 2011 & $\begin{array}{l}1199 \mathrm{Ns} \\
(67.72)\end{array}$ & 1201 & $\begin{array}{c}1210 \mathrm{Ns} \\
(-0.74)\end{array}$ & 11794 & $\begin{array}{l}10109 * \\
(16.66)\end{array}$ & 5900 & $\begin{array}{c}5628 \\
* * * \\
(4.83)\end{array}$ & 1215 & $\begin{array}{c}1209 \mathrm{NS} \\
(0.49)\end{array}$ \\
\hline Total Cost & 8107 & $\begin{array}{c}7759 * * * \\
(4.48)\end{array}$ & 3833 & $\begin{array}{c}2192^{* * * *} \\
(74.86)\end{array}$ & 2782 & $\begin{array}{l}2837 * * \\
(-1.93)\end{array}$ & 13123 & $\begin{array}{c}11481 * * \\
(14.30)\end{array}$ & 8459 & $\begin{array}{c}8355 * * \\
(1.24)\end{array}$ & 2457 & $\begin{array}{c}2626 * * * \\
(-6.43)\end{array}$ \\
\hline
\end{tabular}

Note: $* * *, * * \& *$ indicate 1,5 and 10 per cent level of Significance, respectively; Figures in parentheses indicate the percentage change 
Table 8: Economic feasibility of NCU use for reference crops (partial budgeting framework)(Rs/Acre)

\begin{tabular}{|l|c|c|c|c|c|c|}
\hline \multicolumn{1}{|c|}{ Particulars } & Paddy & Tur & Jute & Maize & Sugarcane & Soybean \\
\hline Added cost & 739.33 & 1300 & 0 & 1685.87 & 585 & 1141 \\
\hline Reduced cost & 226.61 & 3 & 62 & 83.67 & 149 & 16 \\
\hline Added return & 2942.69 & 16558 & - & - & - & - \\
\hline Reduced return & - & 321 & 554 & 1964.83 & 5,749 & 3942 \\
\hline B:C Ratio & 4.28 & 10.21 & & 1.21 & 10.11 & 3.46 \\
\hline
\end{tabular}

\section{Figures}

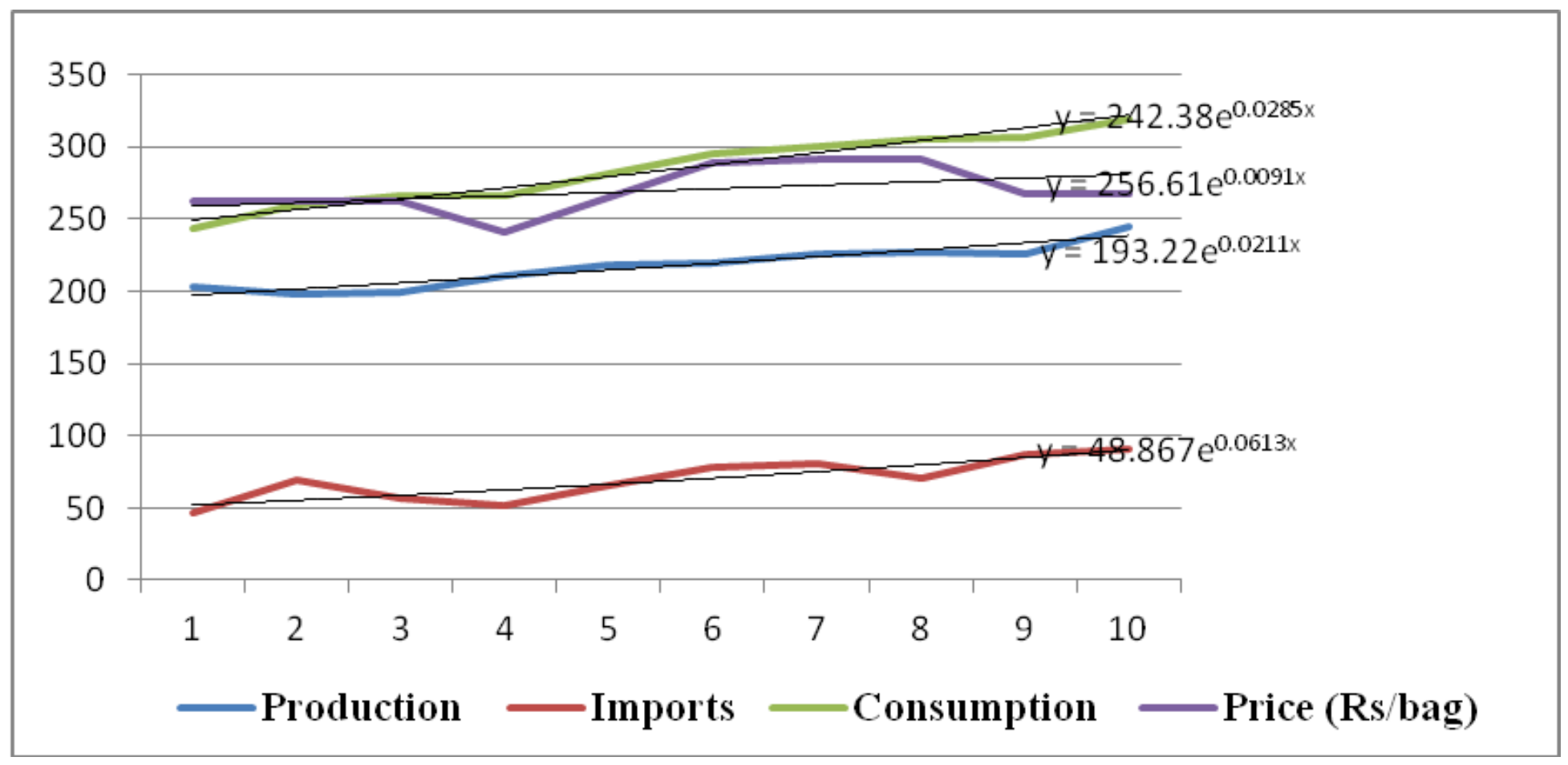

Figure 1

All India urea production, imports, consumption and prices 